\title{
Evaluation of the Olivocochlear Efferent System Activation After Exposure to Music in Young Individuals
}

\author{
Erdoğan Bulut ${ }^{1}$ (D), Elçin Nurçin ${ }^{1}$ (D), Şule Yılmaz (1), Selis Gülseven Güven² (1), Memduha Taş (1) \\ 'Department of Audiology, Trakya University School of Health Sciences, Edirne, Turkey \\ 2Deparment of Otorhinolaryngology, Trakya University School of Medicine, Edirne, Turkey \\ Cite this article as: Bulut E, Nurçin E, Yılmaz Ş, Gülseven Güven S, Taş M. Evaluation of the Olivocochlear Efferent System Activation After \\ Exposure to Music in Young Individuals. JAREM 2019; 9(1): 38-44.
}

\begin{abstract}
Objective: In this study, a protective role of the olivocochlear efferent system activation on the hearing system in young individuals after music exposure (ME) was investigated.

Methods: Twenty two young adults aged 19-22 years (mean age \pm standard deviation, 19.63 \pm 0.83 ) with normal hearing participated in the study. All participants listened to music at 85.4 dBA for 30 minutes. An audiological evaluation including pure tone audiometry, immittance measurements, Distortion Product Otoacoustic Emissions (DPOAEs), and Transient Evoked Otoacoustic Emissions (TEOAEs) with and without contralateral acoustic stimuli (CAS) was done before ME, immediately after ME, and after a rest period.

Results: No significant differences in pure tone audiometry and the DPOAE signal-to-noise ratio (S/N-R) results were found among the three measurement sessions (before $M E$, immediately after $M E$, and after the rest period) in all measured frequencies ( $p>0.05)$. There was a significant increase in the contralateral stapes reflex threshold at $0.5 \mathrm{kHz}$, measured immediately after $\mathrm{ME}(p=0.02)$, while no significant difference was found in the measured frequency after resting $(p>0.05)$. In the TEOAE S/N-R responses, a statistically significant decrease was found at $1 \mathrm{kHz}(\mathrm{p}=0.016)$ and $1.4 \mathrm{kHz}(p=0.009)$ immediately after $\mathrm{ME}$, whereas no significant difference was found between the TEOAE S/N-R responses measured before $\mathrm{ME}$ and after resting $(p>0.05)$. Compared to the conditions before the exposure, there was a statistically significant decrease $(p<0.001)$ in all center frequencies measured immediately after ME and after resting conditions in the TEOAE amplitudes obtained in the presence of CAS.

Conclusion: The contralateral stapes reflex thresholds increase after ME, and a significant suppression effect of the TEOAE amplitudes in the presence of CAS suggests that the olivocochlear efferent system plays a role in protecting the auditory system from acoustic trauma.

Keywords: Efferent pathway, acoustic, noise-induced hearing loss, otoacoustic emission, music
\end{abstract}

\section{INTRODUCTION}

The sound is composed of compressions and rarefactions in the air around us, in other words, the vibrations that occur are a result of drop and increase in pressure (1). The noise usually shows a disgruntled or unwanted sound (2). Approximately 5\% of the world's population has noise-related hearing loss caused by industrial, military, entertainment, and recreational areas. This loss causes major economic costs and damages the quality of life of the affected individual (3). The effects of exposure to noise from entertainment and recreation areas on the hearing system are of particular concern (4). Harris differentiates industrial noise-related hearing loss into three categories: temporary hearing change due to noise, permanent hearing change, and acoustic trauma (5). In the case of noise-induced hearing loss, depending on the intensity and duration of exposure to the hearing organ cochlea, trauma may result in a transient reduction in hearing acuity or a transient threshold change (6). This hearing threshold change due to noise effect is called temporary hearing loss since it goes away after a certain period. It is observed that the hearing thresholds return to normal hearing threshold values after passing 10 times of the exposure time (7). In the case of noise-induced hearing loss, the frequency of 4 $\mathrm{kHz}$ and then $6 \mathrm{kHz}$ and $3 \mathrm{kHz}$ can be audiologically determined. In the course of time, hearing loss affects the frequency of 0.5 $\mathrm{kHz}, 1 \mathrm{kHz}$, and $2 \mathrm{kHz}$ (8). Although hearing threshold changes that start with mild hearing loss (15-20 dB) are not noticed in everyday life or in one-to-one conversations, it causes individuals to have difficulty in distinguishing speech in environments with background noise (9). Studies have shown that temporal hearing threshold changes may improve age-related hearing loss even after a short time (10), and that noise exposure from

ORCID IDs of the authors: E.B. 0000-0003-2036-6870; E.N. 0000-0002-4740-7401; Ş.Y. 0000-0002-4342-5063; S.G.G. 0000-0002-7862-0758; M.T. 0000-00028937-7212. 
entertainment and recreation areas adversely affects quality of life by increasing age-related hearing loss (3). Reporting the increase in the prevalence of noise-induced hearing loss in the early stages of life increases concerns about the long-term effects of noise exposure in young ears (11). The noise-induced hearing loss in workers due to workplace noise in the past is now evident in the form of hearing loss due to noise from environmental conditions or entertainment venues (12). In recent years, the rapid expansion of listening music with portable MP3 players and mobile phones has significantly increased the exposure to loud sound intensity levels (13), and especially in young population listening to their favorite music can be a risk factor for permanent hearing loss. In these studies, it has been shown that listening to music with these devices at $100 \mathrm{dBA}$ for $15 \mathrm{~min}$ is same as a worker who has to work $8 \mathrm{~h}$ in a noisy workplace at a level of $85 \mathrm{dBA}$ (14). Preferred high listening levels range from $60 \%$ to $90 \%$ of the gain setting of the MP3 player, which corresponds to output levels between 82.52 dBA and 98.70 dBA (15). In a survey of personal listening device consumers, approximately two-fifths of college students and adults were found to typically listen to music at a "high" volume with an MP3 player (16). The effect of the MP3 player on the external ear canal being measured at high levels up to $110 \mathrm{dBA}(17)$ and the increase in the prevalence of music-induced hearing loss (18) increased the importance of investigating the effect of the MP3 player on the hearing function. While studies on transient hearing threshold changes in humans (6) are defined over the daily exposure times (usually 5 days per week) annually, typically, $4 \mathrm{kHz}$ for the first $10-15$ years and $2 \mathrm{kHz}$ for the first $10-20$ years have been shown to increase the threshold of hearing in the fastest way.

The characteristic pathological feature of noise-induced hearing loss is the loss of hairy cells (19). In studies on the temporal bone performed in human subjects who were exposed to chronic occupational noise for 30 years, the loss of internal hairy cells in the basal rotation of the cochlea was limited, but a significant loss of external hairy cells (DTH) was observed (20). In experimental animal studies (21-23), the primary target cell group has been reported to be DTH at acute noise-induced hearing loss. Together with the increase in the duration and intensity of the noise, this causes the structural deterioration in the internal hairy cells and the entire Corti Organ (23). It has been shown that auditory sensitivity decreases by 40-60 dB in external hair loss (24). Otoacoustic emissions (OAE) are considered as an important measurement method to detect early cochlear damage caused by noise-induced hearing loss; and DTH activity can be shown by OAEs as a result of intense noise exposure $(25,26)$. Therefore, the absence or low levels of OAE responses are a pre-clinical marker of inner ear injury (27). Furthermore, OAEs allow the investigation of the olivocochlear efferent hearing system with ipsilateral, contralateral, or binaural acoustic stimuli as non-invasive (28). The olivocochlear system consists of lateral and medial fibers extending from the superior oliver complex in the brain stem to the cochlea (12). While lateral fibers showing ipsilateral function synapse with nerve fibers in the cochlea inner hair cells, the contralateral medial fibers make synapses with DTH (29).
It is thought that medial olivocochlear (MOK) fibers help protect the hearing system from acoustic trauma through external hair cells and facilitate speech discrimination in noisy environments (30). With the OAE measurements, it is possible to evaluate the function of the MOK system objectively (31). The OAE values reflecting the response of the outer hairy cells to the sound stimulus are stated to be lower than that of the contralateral stimulus when the contralateral acoustic warning (KAU) is given during the measurement; and this decrease is due to the suppressive effect of the MOK system on DTH (32). Therefore, olivocochlear efferent reflex, measured using KAU, is recommended as a tool to assess the sensitivity of noiseinduced hearing loss (33). In the literature, it has been reported that exposure to music for a $30 \mathrm{~min}$ MP3 player may cause a significant reduction in distortion product otoacoustic emission (DPOAE) amplitudes, even when there is no change in the threshold of hearing (34). Other studies have shown that in exposure to noise exceeding $90 \mathrm{dBA}$ and exposure time varying between 1 and $4 \mathrm{~h}$ lead to a decrease in OAE amplitudes and transient threshold change, respectively $(4,15)$. For the application of noise on the hearing effects areas, sound levels are usually measured after being passed over a standardized filtering network known as A-weighting and weakens the amplitude of the sound at frequencies below $0.5 \mathrm{kHz}$ and above $10 \mathrm{kHz}$. The perceived loudness and sound levels measured by this filtering network were determined as $\operatorname{dBA}(4,6)$.

In our study, the effect of olivocochlear efferent system on hearing system was investigated for 30 min after exposure to music at a sound level of $85.4 \mathrm{dBA}$ in young and adult individuals.

\section{METHODS}

\section{Participants}

After obtaining the approval of the ethics committee and the written informed consent form from the volunteers, the research was conducted on 22 young and adult individuals, including 11 boys and 11 girls. The age of the young and adult individuals in the study ranged from 19 to 22 years (mean age $\pm S D=19.63 \pm 0.83$ ). Individuals who voluntarily participated in the study did not have any systemic disease after otoscopic examination and audiological evaluation, ototoxic drug use, exposure to acoustic trauma, past ear disease and hereditary family history of ear disease, and who had normal hearing were included in the study.

\section{Research Protocol}

In the audiologic evaluation, immitansmetric and pure voice audiometric measurements, transient evoked otoacoustic emission (TEOAE), and DPOAE tests were conducted. The TEOAE responses were evaluated in the presence and absence of CAl. The whole test protocol was repeated at each stage before the exposure to music (BEM), after 30 min of music exposure (ME30) and 10 times the exposure time (ME300) $(=300$ min). All participants who participated in the study were played with the same iPhone headphones (Apple Inc.) for 30 min with the same music playlists created on the iPhone 4s A1387 model 
(iOS 5.0, 16 GB, Apple Inc.) mobile phone. Before playing music playlists in each participant, the device output was set to the maximum volume, and the audio output level in dBA was measured using the 2 cc coupler (Gras-Ra0038, Denmark) with Sound Level Meter (Larson Davis-824, NY USA) at a level of 30 $\min 85.4 \mathrm{dBA}$.

\section{Audiological Reviews}

\section{Immitansmetric Measurements}

The impedance measurements were performed on AT235H device (Interacoustıcs, Taastrup, Denmark) using TDH - 39 (Telephonics, USA) headphones at $226 \mathrm{~dB}$ prop toned $75 \mathrm{~dB}$ SPL. The contralateral stapes reflex thresholds in the range of 0.5-4 $\mathrm{kHz}$ were evaluated. The peak curve A-type was considered as normal tympanogram in the $+100 \mathrm{daPa}$ and $-50 \mathrm{daPa}$ pressure range.

\section{Pure Sound Audiometry}

Since the normal hearing of volunteer individuals is a criterion especially in the formation of the research sample, the normality of hearing was evaluated in all young and adult individuals. The audiological evaluation for the presence of normal hearing included the measurements of pure audio audiometry (Interacoustic AC 40 Clinical Audiometry, Denmark) and immitansmetric (Interacoustic AT 235H, Denmark). Audiometric evaluations were performed by standard audiometric evaluation procedures according to ANSI standards. All pure voice airway audiometric evaluations were made using Telephonic TDH-39 (Telephonics, USA) headphones in the range of 0.25-8 $\mathrm{kHz}$, while bone path assessments were performed using the Radioear B-71 (Radioear, USA) brand bone path vibrator in the range of $0.5-4 \mathrm{kHz}$. The hearing capacity of individuals with the normal tympanogram of type $A$, the presence of stapes reflexes, and the bilateral hearing being $20 \mathrm{~dB} \mathrm{HL}$ or less were evaluated as normal.

\section{DPOAE}

The evaluation of external hair cell function was performed with DPOAE test in 2f1-f2 mode using the ILO 292 USB II Echoport and Clinical OAE ILO V6 software (Otodynamics, London). For $\mathrm{f} 2$ and $\mathrm{f} 1$ frequency, the ratio was kept at the rate of $\mathrm{f} 2 / \mathrm{f} 1$ : 1.22 , the stimulus intensity $\mathrm{f} 1$ frequency was $L 1=65 \mathrm{~dB} \mathrm{SPL}$, and the frequency $\mathrm{f} 2$ was kept at $\mathrm{L} 2=55 \mathrm{~dB}$ SPL. The results were measured in the geometric mean of $\mathrm{f} 1$ and $\mathrm{f} 2$ primary tones in $2 \mathrm{f} 1-\mathrm{f} 2$ mode. At frequencies between $1 \mathrm{kHz}$ and $8 \mathrm{kHz}$, the signal values of the noise threshold above $3 \mathrm{~dB}$ SPL were considered to be significant, and the results obtained in the DPOAE test were based on the signal to noise ratio $\mathrm{kabul}$ signal/noise ratio (S/N-R) (35).

\section{TEOAE and Contralateral Acoustics}

The TEOAE measurements were also performed in the absence and presence of contralateral stimuli for cases included in the study. All OAE measurements were performed in a binaural manner using the ILO 292 Echoport USB II and ILO V6 Clinical OAE software (Otodynamics, London). The probe was calibrated using the $1 \mathrm{cc}$ calibration gap provided by the manufacturer prior to each measurement session. In the TEOAE test parameters, for nonlinear measurements, 260 excitation was performed at $80 \pm 4 \mathrm{~dB}$ peSPL with binaural stimulation at $50 \mathrm{~s}$ per second and noise exclusion level was kept at $45 \mathrm{dBSPL}$ and below. The S/N-R responses at $1 \mathrm{kHz}, 1.4 \mathrm{kHz}, 2 \mathrm{kHz}, 2.8 \mathrm{kHz}$, $4 \mathrm{kHz}$ center frequencies were measured in BEM, ME30, and ME300. While the TEOAE test measurements were performed by giving KAU, $80 \times 4 \mathrm{~dB}$ peSPL was used in a single ear with a linear 80 laterals per second stimulus. Binaural measurements were made at $1 \mathrm{kHz}, 1.4 \mathrm{kHz}, 2 \mathrm{kHz}, 2.8 \mathrm{kHz}, 4 \mathrm{kHz}$ central frequencies, and suppression responses were compared with TEOAE responses in the presence of contralateral acoustic stimuli. The signal amplitudes of TEOAE measurements were examined. For the calculation of suppression amplitudes, the difference between the values obtained in the absence of contralateral stimuli and the values obtained in the presence of contralateral stimuli were calculated (36).

\section{Statistical Analysis}

Data were analyzed using the Statistical Package for Social Sciences program version 17 (SPSS Inc., Chicago, IL, USA). The normality of the distribution of data was tested with the Kolmogorov-Smirnov test; audiological evaluation data were given via mean \pm standard deviation, post-hoc multiple comparison test with one-way ANOVA test in BEM, ME30, and ME300 stages; paired Sample t-test was used for intra-group comparison. Statistical significance was accepted as $p<0.05$.

\section{RESULTS}

There was no statistically significant difference in the audiological evaluations of BEM, ME30, and ME300 in all participants in terms of hearing thresholds between $0.25 \mathrm{kHz}$ and $8 \mathrm{kHz}$ in all three stages in pure sound audiograms ( $p>0.05$ ). Figure 1 shows the average values of hearing thresholds in the pure voice audiograms of volunteers. In the impedance measurements (Figure 2), stapes reflexes measured contralaterally showed a statistically significant decrease in the measurements made immediately after the listening music at 0.5 $\mathrm{kHz}$ for $30 \mathrm{~min}(p=0.02)$. There was no significant difference in $4 \mathrm{kHz}$ ( $p>0.05$ ). In comparison of music exposure and resting for 300 min, no statistically significant difference was found in the stapes reflex thresholds measured at $0.5 \mathrm{kHz}, 1 \mathrm{kHz}, 2 \mathrm{kHz}$, and $4 \mathrm{kHz}(p>0.05)$. When we evaluated the TEOAE measurement results, there was a statistically significant decrease in the $\mathrm{S} / \mathrm{N}-\mathrm{R}$ responses at $1 \mathrm{kHz}(p=0.016)$ and $1.4 \mathrm{kHz}(p=0.009)$ immediately after listening to music at the central frequencies before the exposure (Figure 3). No significant decrease was observed in the $2 \mathrm{kHz}, 2.8 \mathrm{kHz}$, and $4 \mathrm{kHz}$ center frequencies. After $300 \mathrm{~min}$, no statistically significant difference was found in all measurement frequencies $(p>0.05)$. When we evaluated the DPOAE measurements (Figure 4), there was no statistically significant difference between $1 \mathrm{kHz}$ and $8 \mathrm{kHz}$ when the $\mathrm{S} / \mathrm{N}-\mathrm{R}$ responses were compared at times of before music exposure, immediately after listening and after $300 \mathrm{~min}(p>0.05)$. There was no statistically significant difference in the TEOAE ampli- 
tude values in the presence and absence of CAl in the right and left ears in BEM, ME30, and ME300 measured values ( $p>0.05$ ). Therefore, the measurements of MEO, ME30, and ME300 minutes were evaluated together with the measurements obtained from the left and right ears and statistical analyses were performed over 44 ears.

Figure 5 shows the difference between the TEOAE amplitude values in terms of MET, ME30, and ME300 minutes post-suppression. While the TEOAE amplitude values measured in the absence and presence of contralateral acoustic stimuli were compared at $1 \mathrm{kHz}, 1.4 \mathrm{kHz}, 2 \mathrm{kHz}, 2.8 \mathrm{kHz}$, and $4 \mathrm{kHz}$ central frequencies, there was no statistically significant difference ( $p>0.05)$. In the measurements performed after 30 min of listening music, a statistically significant difference was found in all central frequencies $(p<0.001)$. When the measurements were made after 300 min or after the rest, a statistically significant difference was obtained, similar to measurements made after music exposure $(p<0.0002)$.

\section{DISCUSSION}

In recent years, studies have shown that especially in young people, increased attention to portable personal music devices (MP3 player, IPod, mobile phones) causes noise-induced hearing loss, because of which age-related hearing loss occurs

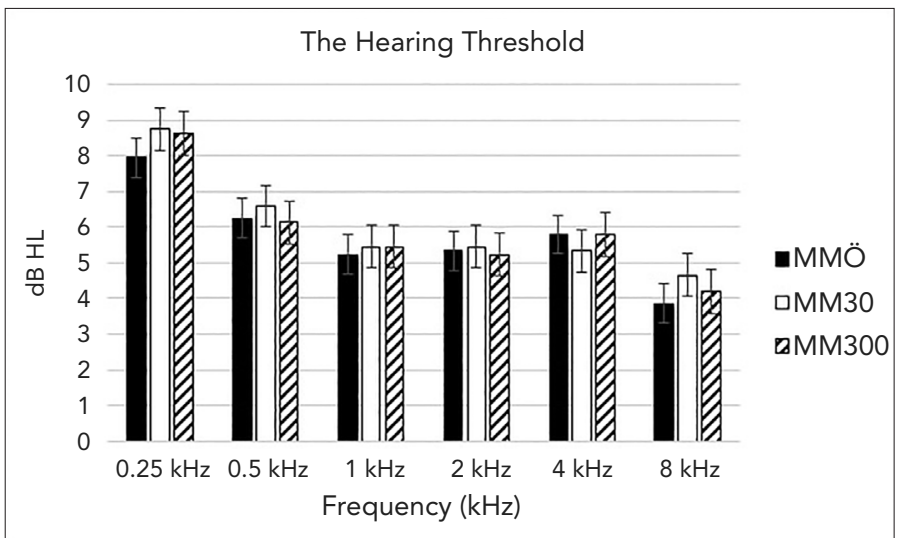

Figure 1. The hearing threshold of young individuals before exposure to music, $30 \mathrm{~min}$ after exposure, and after $300 \mathrm{~min}$

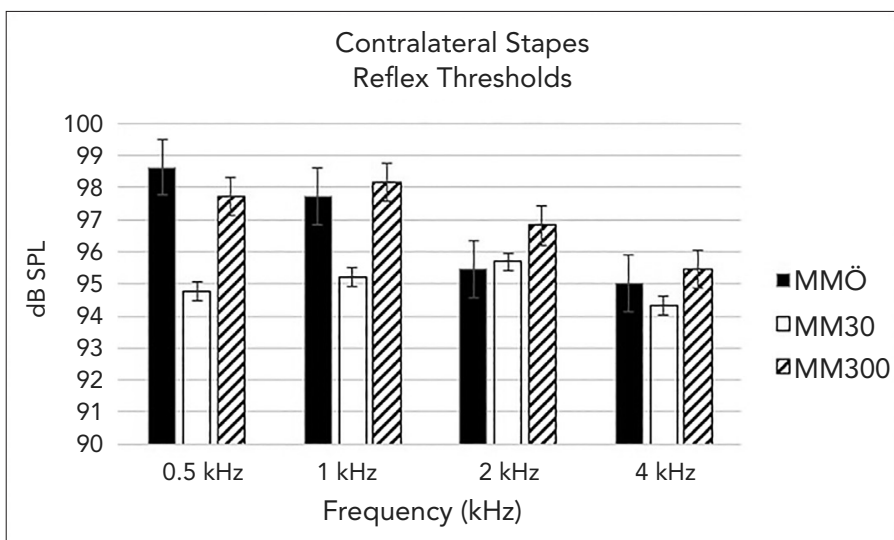

Figure 2. Contralateral stapes reflex thresholds of young individuals before exposure to music, $30 \mathrm{~min}$ after exposure, and after $300 \mathrm{~min}$ in the early stages of life $(4,10,12,13)$. The efferent hearing system plays an important role in auditory perception in humans. The medial part of the most studied efferent system, namely the MOK system, helps to protect the auditory system from acoustic trauma, as well as being important for distinguishing speech from the localization of the sound source, auditory attention, improved perception of acoustic signals, and background noise $(30,33)$. Another mechanism of the auditory system, which protects against acoustic trauma, is the acoustic

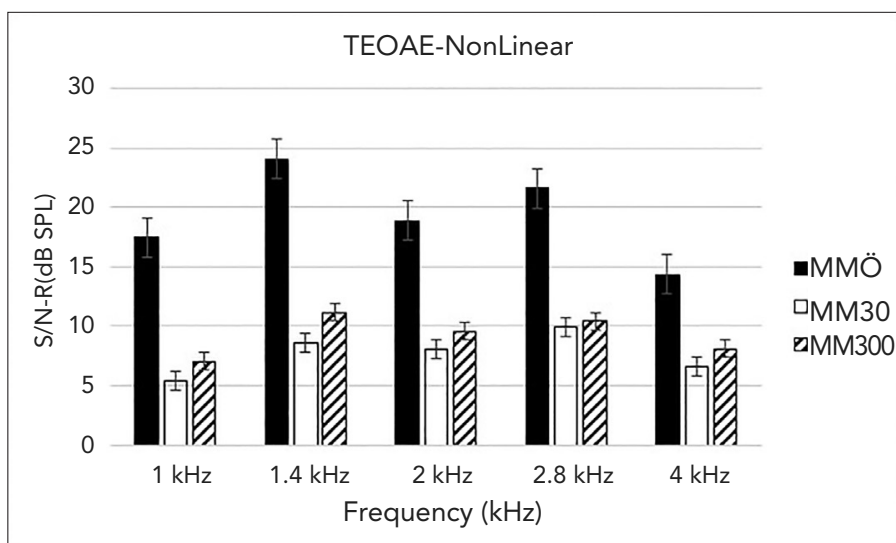

Figure 3. The TEOAE S/N-R responses of young individuals before exposure to music, $30 \mathrm{~min}$ after exposure, and after $300 \mathrm{~min}$

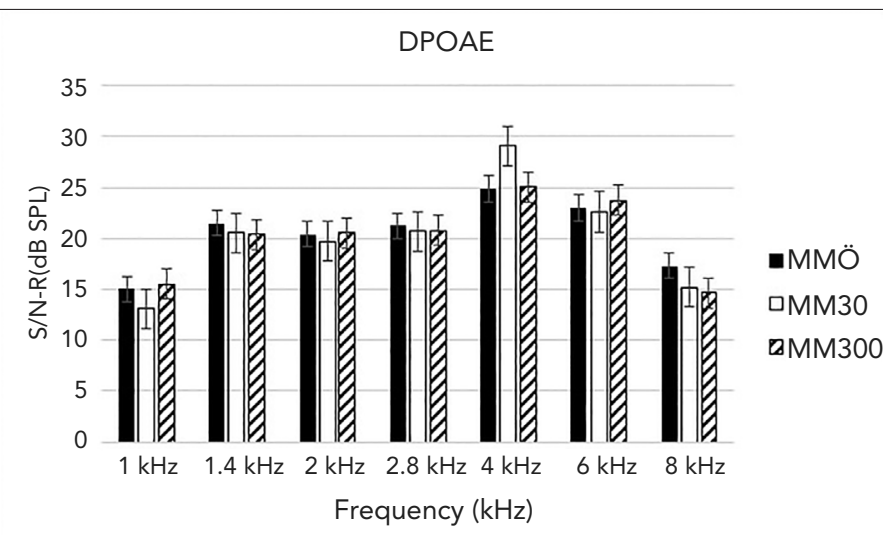

Figure 4. The DPOAE S/N-R responses of young individuals before exposure to music, $30 \mathrm{~min}$ after exposure, and after $300 \mathrm{~min}$

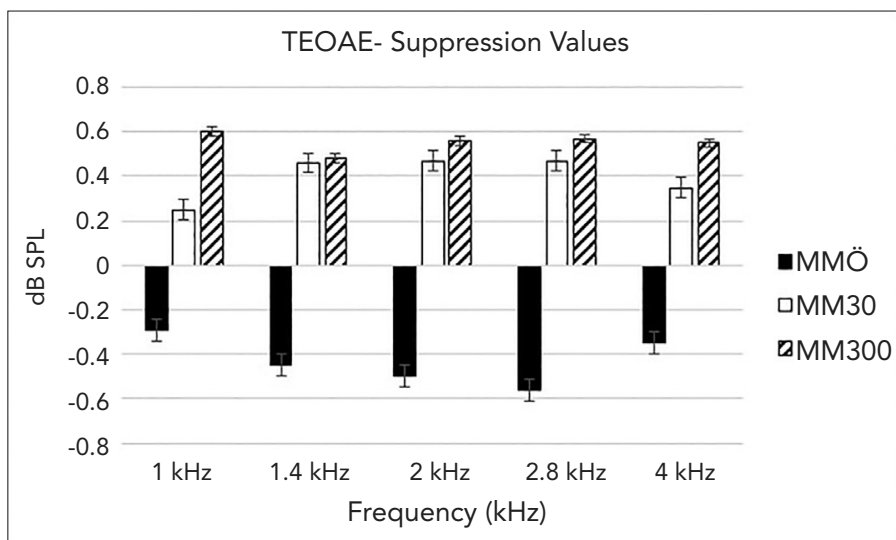

Figure 5. The TEOAE suppression values of young individuals before exposure to music, $30 \mathrm{~min}$ after exposure, and after $300 \mathrm{~min}$ 
reflex that enables the contraction of the stapes muscle and decreases the volume of the voice in the face of a high-intensity sound stimulus (37). The contralateral suppression of the acoustic reflex can be an indicator to assess the function of the efferent system in high-intensity sound stimuli, and this contralateral suppression may also be detected as an amplitude drop or threshold increase in the middle ear muscle reflex (38). Thus, in this study, acoustic reflex responses and MOK activations of young individuals were evaluated in terms of the protection of the auditory system. The decrease in OAE amplitudes in the presence of contralateral stimuli is a result of suppression of external hairy cell activation due to the effect of MOK efferent system (39). In experimental studies (40-42), it has been shown that electrical or acoustic stimulation of the MOK efferent system prevents transient threshold changes. The dissociation of the MOK efferent system increased the permanent threshold changes after noise exposure (40-43), and it was found that the olivocochlear efferent reflex or MOK efferent system was a non-invasive method to measure the sensitivity in noise-induced hearing loss (43). In a study conducted by Hannah et al. (15) who evaluated MOK activation especially in terms of transient threshold changes, the exposure to music was measured at $82.52 \mathrm{dBA}, 87.46 \mathrm{dBA}, 92.25 \mathrm{dBA}$, and $98.70 \mathrm{dBA}$, respectively. The TEOAE amplitude values measured in the presence and absence of KAU before and after exposure were not statistically significant. In our study, a statistically significant suppression effect was observed in the TEOAE amplitude values obtained before and after the exposure, especially in the presence of $\mathrm{KAU}$, suggesting that the olivocochlear efferent system is important for acoustic trauma. During the studies performed on the stapes reflex arch of the efferent system, it was shown that the stapes muscle contracted (43) during the continuation of the noise and the muscles became continuous exercise with the chronic noise and the productivity increased (44). Weidenar (45) and Sarikaya (46) performed acoustic reflex latency with an intensity of more than $10 \mathrm{~dB}$ at $0.5 \mathrm{kHz}$ and a contralateral stimulation for $5 \mathrm{~min}$ at $0.5 \mathrm{kHz}$, and especially, they showed that reflex decay was not related to chronic noise exposure in this method they proposed for the differential diagnosis of noiserelated hearing loss.

For this purpose, we evaluated the reflex thresholds as contralateral rather than acoustic reflex latencies because of music exposure in young individuals; and we obtained increase in the threshold responses in a manner that supports the studies conducted at the recommended $0.5 \mathrm{kHz}$ for the differential diagnosis of noise-induced hearing losses. There are many studies on the effect of amplified music on auditory system properties. In portable personal music listening devices, a 5-5.5 dB increase is observed at the volume because of the volume of the external ear canal. In a study (47) on the sound output levels in six portable devices with a difference of $5 \%-10 \%$ in the sound settings, the average measured noise level was shown to be $85 \mathrm{dBA}$; and this noise level changed from $80 \mathrm{dBA}$ to $110 \mathrm{dBA}$. In our study, we created an average noise level of $85.6 \mathrm{dBA}$ for $30 \mathrm{~min}$ in young individuals to create music exposure and when evaluated in terms of hearing thresholds at this level, we did not obtain a statistically significant difference especially between 2 and $8 \mathrm{kHz}$, similar to the findings of Trzaskowski (48) and Bhagat (34). In other studies conducted (25-27), it has been suggested that noise exposure changes in the $\mathrm{OAE}$ parameters without changing the hearing thresholds of individuals, and it may be a diagnostic marker for noise-induced hearing loss in the inner ear. In a long-term study conducted on 338 volunteers on an aircraft carrier, the values of pure sound audiograms, TEOAE and DPOAE measured before and after 6 months of exposure to noise were significantly reduced, whereas no significant changes were observed in the hearing thresholds of individuals (25). In our findings, a statistically significant decrease in TEOAE S/N-R responses of $1 \mathrm{kHz}$ and 1.4 $\mathrm{kHz}$ in young individuals after music exposure was supported, but there was no significant change in the DPOAE responses. In another study conducted on 28 young volunteers, there were no statistically significant changes in the auditory thresholds in the audiological evaluations before, after and after the exposure; significant changes in the OAE parameters have been obtained (15). In the studies, it was shown that noise above 90 $\mathrm{dBA}$ caused temporary hearing threshold change; if it was continuous, it led to permanent threshold change, and this change was found to be $4-8 \mathrm{kHz}(49,50)$.

\section{CONCLUSION}

In our study, we found that music exposure at $85.4 \mathrm{dBA}$ for $30 \mathrm{~min}$ did not cause any change in threshold responses and DPOAE responses on pure voice audiogram for portable personal listening devices. However, $0.5 \mathrm{kHz}$ contralateral stapes reflex threshold increase in music exposure, decrease in TEOAE nonlinear S/N$R$ responses, and suppression of TEOAE linear amplitudes observed in the presence of CAl suggest that these tests may have a protective role in the face of acoustic trauma and the olivocochlear efferent system.

Ethics Committee Approval: Ethics committee approval was received for this study from the Ethics Committee of Scientific Researches of Trakya University School of Medicine (Approval number: TÜTF- BAEK 2015/207).

Informed Consent: Written informed consent was obtained from voluntaries who participated in this study.

Peer-review: Externally peer-reviewed.

Author Contributions: Concept - E.B., E.N., M.T.; Design - E.B., Ş.Y., M.T., S.G.G.; Supervision - E.B., S..Y., M.T., E.N., S.G.G.; Resources - E.B.,E.N., S.Y., M.T.; Materials - E.B., M.T., E.N.; Data Collection and/or Processing - E.N., E.B., M.T.; Analysis and/or Interpretation - M.T., E.B., S.G.G.; Literature Search - Ş.Y., M.T., E.B., E.N., S.G.G.; Writing Manuscript - E.B., M.T., Ş.Y., S.G.G.; Critical Review - Ş.Y., E.B., M.T., S.G.G.; Other - E.B, Ş.Y., M.T., E.N., S.G.G.

Conflict of Interest: The authors have no conflict of interest to declare.

Financial Disclosure: The authors declared that this study has received no financial support.

\section{REFERENCES}

1. Bulut E. Corti organı frekans seçiciliğinde dış tüylü hücrelerin rolü. (Doktora Tezi). Edirne: Trakya Üniv. 2009. 
2. Devren M. Gürültüye Bağlı Iş̧itme Kayıplı Olguların Odyolojik Bulguları ve Psiko-sosyal Yönden Karşılaştııılması. Edirne: Trakya Üniv. 1998.

3. Oishi N, Schacht J. Emerging treatments for noise-induced hearing loss. Expert Opin Emerg Drugs 2011; 16: 235-45. [CrossRef]

4. Keppler H, Dhooge I, Maes L, D'haenens W, Bockstael A, Philips B, et al. Short-term auditory effects of listening to an MP3 player. Arch Otolaryngol Head Neck Surg 2010; 136: 538-48. [CrossRef]

5. Haris JD. Audition. Ann Rev Psychol 1972; 23: 313-46. [CrossRef]

6. Humes L, Joellenbeck LM, Durch J, editors. Noise and Milıtary Service. Implications for hearing loss and tinnitus. Washington DC: National Academies Press; 2001.

7. Esmer N, Akıner M, Karasalihoğlu A.R, Saatçi M. Klinik Odyoloji. Ankara: Bilim Yayınları; 1995.

8. Şenkal ÖA, Aydın E. Havacılıkta İşitme ve Gürültüye Bağlı İşitme Kayıpları. KBB ve BBC Dergisi 2013; 21: 47-54.

9. Bess FH, Humes L. Audiology: the fundamentals. 4th ed. Philadelphia: Lippincott Williams \&Wilkins; 2008.

10. Kujawa SG, Liberman MC. Acceleration of age-related hearing loss by early noise exposure: evidence of a misspent youth. J Neurosci 2006; 26: 2115-23. [CrossRef]

11. Folmer RL, Griest SE, Martin WH. Hearing conservation education programs for children: a review. J Sch Health 2002; 72: 51-7. [CrossRef]

12. Yu J, Lee D, Han W. Preferred listening levels of mobile phone programs when considering subway interior noise. Noise Health 2016; 18 : 36-41. [CrossRef]

13. Naik K, Pai S. High frequency hearing loss in students used to ear phone music: A randomized trial of 1,000 students. J Otol 2014; 20: 29-32. [CrossRef]

14. Kageyama T. Loudness in listening to music with portable headphone stereos. Percept Mot Skills 1999; 88: 423. [CrossRef]

15. Hannah K, Ingeborg D, Leen M, Annelies B, Birgit P, Freya $S$, et al. Evaluation of the olivocochlear efferent reflex strength in the susceptibility to temporary hearing deterioration after music exposure in young adults. Noise Health 2014; 16: 108-15. [CrossRef]

16. Zogby International. 2006. Survey of Teens and Adults about the Use of Personal Electronic and Head Phones. Available from: http://www.asha. org/NR/rdonlyres/10B67FA1-002C-4C7B-BA0B1C0A3AF98A63/0/zogby_survey2006.pdf. Retrieved December 20, 2007.

17. Hodgetts WE, Rieger JM, Szarko RA. The effects of listening environment and earphone style on preferred listening levels of normal hearing adults using an MP3 player. Ear Hear 2007; 28: 290-97. [CrossRef]

18. Morata TC. Young people: Their noise and music exposures and the risk of hearing loss. Int J Audiol 2007; 46: 111-2. [CrossRef]

19. Schuknecht HF. Pathology of the ear. Cambridge, Mass: Harvard University Press; 1974

20. Nakamoto Y, lino Y, Kodera K. Temporal bone histopathology of noise-induced hearing loss. Nippon Jibiinkoka Gakkai Kaiho 2005; 108: 172-81. [CrossRef]

21. Bulut E, Uzun C, Öztürk L, Turan P, Kanter M, Arbak S. A New Hypothesis on the Frequency Discrimination of the Cochlea. J Int Adv Otol 2017; 13: 204-10. [CrossRef]

22. Yildirim C, Yağiz R, Uzun C, Taş A, Bulut E, Karasalihoğlu A. The protective effect of oral magnesium supplement on noise-induced hearing loss. Kulak Burun Bogaz Ihtis Derg 2006; 16: 29-36.

23. Hirose K, Liberman MC. Lateral wall histopathology and endocochlear potential in the noise damaged mouse cochlea. J Assoc Res Otolaryngol 2003; 4: 339-52. [CrossRef]

24. Ryan A, Dallos P. Effect of absence of cochlear outer hair cells on behavioural auditory threshold. Nature 1975; 253: 44-6. [CrossRef]
25. Lapsley Miller JA, Marshall L, Heller LM, Hughes LM. Low-level otoacoustic emissions may predict susceptibility to noise-induced hearing loss. J Acoust Soc Am 2006; 120: 280-96. [CrossRef]

26. Marshall L, Lapsley Miller JA, Heller LM, Wolgemuth KS, Hughes LM, Smith SD, et al. Detecting incipient inner-ear damage from impulse noise with otoacoustic emissions. J Acoust Soc Am 2009; 125: 9951013. [CrossRef]

27. Lapsley Miller JA, Marshall L. Otoacoustic emissions as a preclinical measure of noise-induced hearing loss and susceptibility to noiseinduced hearing loss. In: Robinette MS, Glattke TJ, editors. Otoacoustic Emissions: Clinical Applications. New York: Thieme Medical Publishers; 2007. p. 321-41.

28. Collet L, Veuillet E, Bene J, Morgon A. Effects of contralateral White noise on click-evoked emissions in normal and sensorineural ears: Towards an exploration of the medial olivocochlear system. Audiology 1992; 31: 1-7. [CrossRef]

30. Guinan JJ. Jr. Olivocochlear Efferents; Anatomy, Physiology, Function, and the Measurement of Efferent Effects in Humans. Ear Hear 2006; 27: 589-607. [CrossRef]

31. Muchnik C, Rotha DAE, Othman-Jebaraa R, Putter-Katz H, Shabtai EL, Hildesheimera M. Reduced Medial Olivocochlear Bundle System Function in Children with Auditory Processing Disorders. Audiol Neurootol 2004; 9: 107-14. [CrossRef]

32. Collet L, Kemp DT, Veuillet E, Duclaux R, Moulin A, Morgon A. Effects of contralateral auditory stimuli on active cochlear micro-mechanical properties in human subjects. Hearing Research 1990; 43: 251-62. [CrossRef]

33. Guinan JJ Jr, Backus BC, Lilaonitkul W, Aharonson V. Medial olivocochlear efferent reflex in humans: Otoacoustic emission (OAE) measurement issues and the advantages of stimulus frequency OAES. J Assoc Res Otolaryngol 2003; 4(4):521-40. [CrossRef]

34. Bhagat SP, Davis AM. Modification of otoacoustic emissions following ear-level exposure to MP3 player music. Int J Audiol 2008; 47: 751-60.

35. Hall JW, McCoy MJ, Whitehead ML, Martin GK. Clinical testing of distortion-product otoacoustic emissions. Ear Hear 1993; 14: 11-22. [CrossRef]

36. Didone DD, Kunst LR, Weich TM, Tochetto TM, Mota HB. Function of the medial olivocochlear system in children with phonological disorders. J Soc Bras Fonoaudiol 2011; 23: 358-63.

37. Kumar A, Barman A. Effect of efferent-induced changes on acoustical reflex. Int J Audiol 2002; 41: 144-7. [CrossRef]

38. Mishra SK. Medial efferent mechanisms in children with auditory processing. Front Hum Neurosci 2014; 8: 860. [CrossRef]

39. Bulut E, Yılmaz S, Tas M, Türkmen M T, Polat Z. Contralateral Suppression of Transient Evoked Otoacoustic Emissions in Children with Fluency Disorders. JAREM 2017; 7: 144-48. [CrossRef]

40. Cody AR, Johnstone BM. Temporary threshold shift modified by binaural acoustic stimulation. Hear Res 1982; 6: 199-205. [CrossRef]

41. Rajan R. Involvement of cochlear efferent pathways in protective effects elicited with binaural loud sound exposure in cats. J Neurophysiol 1995; 74: 582-97. [CrossRef]

42. Rajan R. Frequency and loss dependence of the protective effects of the olivocochlear pathways in cats. J Neurophysiol 1995; 74: 598615. [CrossRef]

43. Maison SF, Liberman MC. Predicting vulnerability to acoustic injury with a noninvasive assay of olivocochlear reflex strength. J Neurosci 2000; 20: 4701-7. [CrossRef]

44. Borg E. On the neuronal organization of the acoustic middle ear reflex. A physiological and anatomical study. Brain Res 1973; 49: 101 23. [CrossRef] 
45. Weidenar H, Lenarz T. Verhalten des stapediusreflexes bei akustchier. Rhinol Otol 1982: 61; 674-77. [CrossRef]

46. Sarıkaya İ, Karasalihoğlu AR, Havza B. Gürültüye bağlı işitme kayıplarının ayırıcı tanısında stapes refleks cevaplarının yeri. Trakya Üniversitesi Tıp Fakültesi Dergisi 1987; 4: 16-21.

47. Fligor BJ, Cox LC: Output levels of commercially available portable compact disc players and the potential risk to hearing. Ear Hear 2004; 25: 513-27. [CrossRef]
48. Trzaskowski B, Jędrzejczak WW, Piłka E, Cieślicka M, Skarżyński H. Otoacoustic emissions before and after listening to music on a personal player. Med Sci Monit 2014; 20: 1426-31. [CrossRef]

49. Hellström PA, Axelsson A, Costa O. Temporary threshold shift induced by music. Scand Audiol Suppl 1998; 48: 87-94.

50. Santos L, Morata TC, Jacob LC, Albizu E, Marques JM, Paini M. Music exposure and audiological findings in Brazilian disc jockeys (DJs). Int J Audiol 2007; 46: 223-31. [CrossRef] 